\title{
Trophic interactions between picophytoplankton and micro- and nanozooplankton in the western Arabian Sea during the NE monsoon 1993
}

\author{
Marcus Reckermann ${ }^{1, *}$, Marcel J. W. Veldhuis ${ }^{2}$ \\ Institut für Ostseeforschung, Seestr. 15, D-18119 Warnemünde, Germany \\ ${ }^{2}$ Instituut voor Onderzoek der Zee, Postbus 59, 1790 AB Den Burg, The Netherlands
}

\begin{abstract}
The grazing pressure of micro- and nanozooplankton on phytoplankton was estimated in serial dilution experiments in the northwestern Arabian Sea and its adjacent areas (the Somali Current, the Somali Basin, the Gulf of Aden and the southern Red Sea) during the NE monsoon 1992-1993. Microzooplankton grazing rates $(g$ ) on total phytoplankton (analyzed as $\mathrm{chl}$ a) were generally exceeded by phytoplankton growth rates $\left(g=0.2\right.$ to $1.19 \mathrm{~d}^{-1}$, mean $0.48 \mathrm{~d}^{-1} ; \mu=0.52$ to $1.12 \mathrm{~d}^{-1}$, mean $\left.0.72 \mathrm{~d}^{-1}\right)$, resulting in an average daily consumption of $38 \%$ of the phytoplankton standing stock and $67 \%$ of the primary production. Microzooplankton grazing on 4 picophytoplankton groups (Prochlorococcus spp., Synechococcus spp., and 2 picoeukaryotes) analyzed by flow cytometry showed growth $(\mu=0.27$ to $0.92 \mathrm{~d}^{-1}$, mean $\left.0.68 \mathrm{~d}^{-1}\right)$ and grazing mortality rates $\left(g=0.26\right.$ to $0.73 \mathrm{~d}^{-1}$, mean $\left.0.67 \mathrm{~d}^{-1}\right)$ well in balance, with an average of $49 \%$ of the standing stock and $102 \%$ of the primary production grazed per day. Picophytoplankton growth and grazing mortality rates increased dramatically when grazers $>10 \mu \mathrm{m}$ were removed. These results suggest a control of the small grazers by larger ones (trophic cascade) and a close coupling between picoautotrophic prey and small grazers. The trophic cascade within the microbial food web of the nanoplankton encompasses 3 trophic levels: picoplankton - small HNF - larger flagellates and ciliates.
\end{abstract}

KEX WORDS: Grazing Picophytoplankton-Prochlorococcus Synechococcus Picoeukaryotes Flow cytometry Arabian Sea Trophic cascade

\section{INTRODUCTION}

Photoautotrophic picoplankton (size 0.2 to $2 \mu \mathrm{m}$ ) often dominates the phytoplankton community within the euphotic zone of oligotrophic oceans (Campbell \& Vaulot 1993, Fogg 1995), and particularly so during the inter-monsoon periods in the Arabian Sea (Burkill et al. 1993, Jochem 1995). The prokaryotic species Prochlorococcus marina (Chisholm et al. 1992) and Synechococcus spp. (Johnson \& Sieburth 1979, Waterbury et al. 1979), as well as eukaryotic algae of various taxonomic groups (Johnson \& Sieburth 1982, Simon et al 1994) are the predominant autotrophs within this size class. In order to assess their role in oceanic carbon flux, information on their growth and grazing mortality

\footnotetext{
-Present address: Forschungs- und Technologiezentrum Westküste, Hafentörn, D-25761 Büsum, Germany.

E-mail: reckermann@ftz-west.uni-kiel.de
}

rates is essential. Knowledge of the size of the principal predators of picoplankton is important as well, as size largely determines the fraction of carbon which is passed on to higher trophic levels (Sherr et al. 1986). Grazing can be assumed to be the most significant loss factor for these organisms, as direct sedimentation is unlikely due to their small size, although they may form a significant component in sinking aggregates (Lochte \& Turley 1988). Prochlorococcus, reaching abundances of up to $350000 \mathrm{~cm}^{-3}$ in the euphotic zone of oligotrophic regions (Olson et al. 1990, Veldhuis \& Kraay 1993, Lindell \& Post 1995, Buck et al. 1996), cannot be discriminated reliably from heterotrophic bacteria by epifluorescence microscopy, due to their dim and fast-fading autofluorescence (Monger \& Landry 1993), and many have been mistakenly counted as heterotrophic bacteria for that reason (Campbell et al. 1994, Sieracki et al. 1995). Although the occurrence of Prochlorococcus was shown in the NW Indian Ocean 
(Pollehne et al. 1993, Veldhuis \& Kraay 1993, Jochem 1995), information on the dynamics of these tiny primary producers has been scarce. To date, information on Prochlorococcus growth rates is available only from the Sargasso Sea (Goericke \& Welschmeyer 1993) and the equatorial Pacific (Vaulot et al. 1995); grazing estimates have been reported only from the equatorial Pacific (Landry et al. 1995a, b). Information on eukaryotic picoplankton dynamics is also rare. For Synechococcus, Burkill et al. (1993) reported high biomasses and turnover rates in the Arabian Sea during the autumn inter-monsoon period.

We report here specific phytoplankton growth and grazing mortality rates by microzooplankton (measured as bulk chl $a$ and as separate picoautotrophic groups by fiow cyiomeliy: Prochlorocuccus, Synechocuccus, 2 picoeukaryotes, and occasionally 2 sub-populations of Prochlorococcus and Synechococcus) at different locations in the Somali Current, the Gulf of Aden, and the southern Red Sea during the NE monsoon period (January-February 1993). The standard dilution protocol of Landry \& Hassett (1982) was modified in order to account for the respective grazing impact of different grazer size classes within the microzooplankton community (grazers $<20,<10,<3$ and $<2 \mu \mathrm{m}$ ).

\section{MATERIAL AND METHODS}

Micro- and nanozooplankton grazing experiments (Landry \& Hassett 1982) were carried out aboard RV 'Tyro' on cruise B2 of the Netherlands Indian Ocean Programme 1992-1993 (Baars et al. 1994) at 8 stations in the Arabian Sea off Somalia, in the Gulf of Aden and the Red Sea (Fig. 1) during the NE monsoon (January-February 1993). Water samples were taken from the upper mixed layer $(10$ to $30 \mathrm{~m})$ on the uphaul with a Seabird CTD rosette water sampler equipped with 10.5 I NoEx bottles. Water samples were prescreened through a $200 \mu \mathrm{m}$ mesh (to remove mesozooplankton) and diluted with particle-free sea-

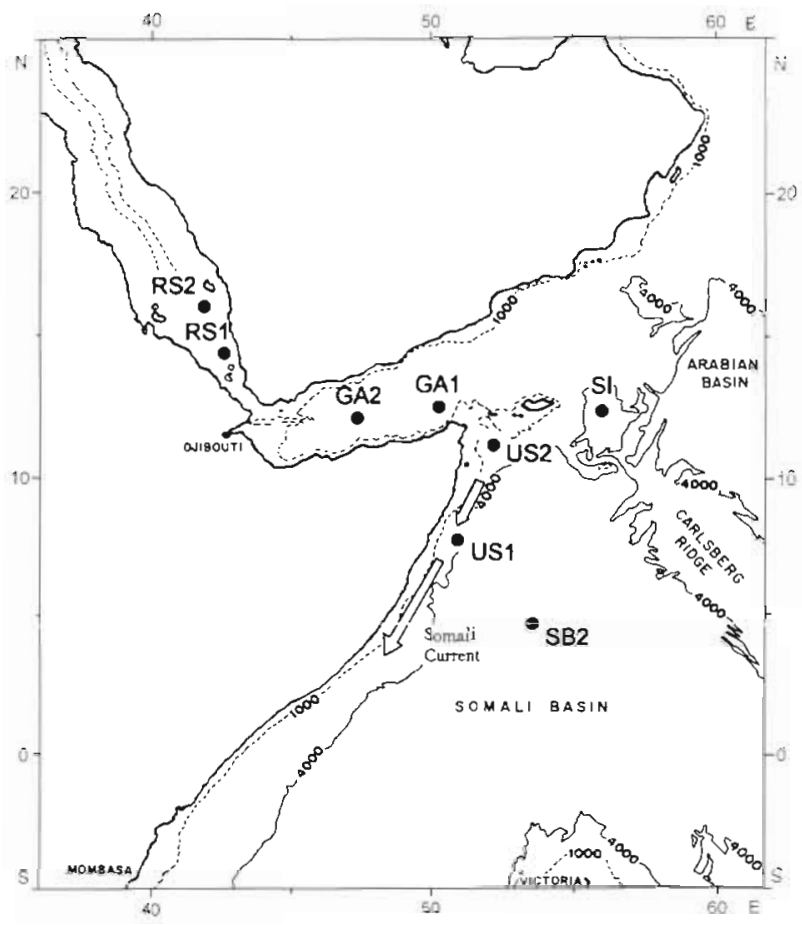

Fig. 1. Investigation area with stations in the Somali Current, the Gulf of Aden and the southern Red Sea. Arrows indicate the direction of the Somali Current during the NE monsoon

water (prepared by sterile, preflushed $0.2 \mu \mathrm{m}$ filter capsules; Nalgene) to give 4 dilution steps $(100,75$, 50 and $25 \%$ original water) and incubated on board in $5 \mathrm{l}$ glass bottles for $24 \mathrm{~h}$, starting at sunrise. In situ conditions were simulated in a light-screened flowthrough bath which ensured mixed layer temperatures and irradiances corresponding to the sampling depths (Table 1). For chl a analyses, samples (1 to 2.5 1) were filtered over a GF/F glass fibre filter $(47 \mathrm{~mm}$; Whatman) at the beginning and at the end of each respective experiment. Filters were stored at $-80^{\circ} \mathrm{C}$ until fluorometric analysis according to Veldhuis et al. (1993)

Table 1 Locations, dates and ambient environmental conditions for the experiments in the Somali Basin (SB2 to SI), the Gulf of Aden (GA1, GA2) and the southern Red Sea (RS1, RS2) during the NE monsoon 1993. FC: flow cytometry

\begin{tabular}{|c|c|c|c|c|c|c|c|}
\hline Expt & $\begin{array}{l}\text { Phytoplankton } \\
\text { analyzed by }\end{array}$ & Stn & $\begin{array}{l}\text { Date } \\
\text { (1993) }\end{array}$ & $\begin{array}{c}\text { Simulated incubation } \\
\text { depth }(\mathrm{m})\end{array}$ & $\begin{array}{l}\text { Temperature } \\
\qquad\left({ }^{\circ} \mathrm{C}\right)\end{array}$ & $\begin{array}{l}\mathrm{NO}_{3} \\
(\mu \mathrm{M})\end{array}$ & $\begin{array}{c}\text { Chl a } \\
\left(\mu \mathrm{g} \mathrm{dm} \mathrm{m}^{-3}\right)\end{array}$ \\
\hline 1 & chl a, FC & SB2 (809-1) & $\operatorname{Jan} 15$ & 20 & 26.9 & 0.13 & 0.35 \\
\hline 2 & chl a, FC & US1 (813-1) & $\operatorname{Jan} 18$ & 20 & 26.7 & 0.23 & 0.28 \\
\hline 3 & chl $a, F C$ & US2 (818-5) & $\operatorname{Jan} 21$ & 20 & 26.0 & 0.80 & 0.30 \\
\hline 4 & ch] $a, F C$ & SI $(820-1)$ & Jan 24 & 20 & 26.0 & 0.93 & 0.25 \\
\hline 5 & chla & GA1 $(826-4)$ & $\operatorname{Jan} 26$ & 20 & 25.9 & 0.30 & 0.50 \\
\hline 6 & chl a, FC & GA2 $(832-11)$ & $\operatorname{Jan} 30$ & 20 & 25.4 & 1.53 & 0.46 \\
\hline 7 & chl a & RS1 $(840-4)$ & Feb 02 & 10 & 25.7 & 0.02 & 0.95 \\
\hline 8 & $\mathrm{chl} a, \mathrm{FC}$ & RS2 (842-14) & Feb 04 & 10 & 25.8 & 0.40 & 1.04 \\
\hline
\end{tabular}


In parallel treatments, the standard serial dilution protocol was modified to the effect that in addition to grazers $>200 \mu \mathrm{m}$, also grazers $>20,>10,>3$ and $>2 \mu \mathrm{m}$ were removed by prescreening in order to determine the respective grazing pressure of smaller grazer size classes on the picoautotroph community. The experimental water was siphoned from the CTD bottle into a light-screened 2 I plastic beaker by means of a submerged silicon tube. The water was prescreened by gravity through meshes (for the size fractions $<20$ and $<10 \mu \mathrm{m}$ ) or presoaked polycarbonate filters (for the smaller fractions) and collected in dark plastic bottles. The prescreened water samples were then combined with particle-free seawater (prepared by preflushed encapsulated $0.2 \mu \mathrm{m}$ syringe filters; Schleicher \& Schuell Red Edge) from the beaker according to the 4 dilution steps (see above) and incubated in parallel in $60 \mathrm{ml}$ polystyrene culture bottles on board under simulated in situ conditions (free floating in a light-screened container flushed with running seawater; see above) for $24 \mathrm{~h}$, starting $1 \mathrm{~h}$ after sunrise. All experimental gear was washed thoroughly with $10 \% \mathrm{HCl}$ and rinsed with $0.2 \mu \mathrm{m}$-filtered seawater. After incubation, the samples were counted immediately, or stored cool in the dark at $4^{\circ} \mathrm{C}$ until counted (up to $3 \mathrm{~h}$ ). Cells were counted with a Coulter Epics CS flow cytometer as described by Veldhuis \& Kraay (1993), with the difference that $458 \mathrm{~nm}$ instead of $488 \mathrm{~nm}$ was used as excitation wavelength.

Chl $a$ and cell concentrations of the respective phytoplankton groups before and after the incubations were used to calculate apparent $(k)$ and specific $(\mu)$ growth rates as well as specific grazing mortality rates $(g)$ according to Landry \& Hassett (1982). Linear regressions of dilution plots (apparent growth rates vs dilution factor) were considered significant at $p \leq 0.05$ Only those data were used for further calculations. Percentages of phytoplankton standing stock consumed per day were calculated as \% cons. $=\left(1-\mathrm{e}^{g}\right) \times$ $100 ;$ percentages of primary production consumed per day as $\%$ cons. $=\left(g^{\prime} / \mu\right) \times 100$. Absolute phytoplankton consumption rates were calculated using the average phytoplankton concentrations $\langle C\rangle$ in the incubation bottles according to Frost (1972): $C_{\text {cons }}=\langle C\rangle \times\left(1-e^{g}\right)$. Chl a-based total phytoplankton carbon consumption rates were estimated using a $C$ : chl a conversion factor of 190 which was determined experimentally by relating flow cytometric cell counts (using the cell-tocarbon conversion factors) and red fluorescence intensities to fluorometrically measured chl a concentrations as described in detail by Veldhuis et al. (1997).

Cell numbers were converted to carbon biomass according to Veldhuis et al. (1997): Synechococcus $175 \mathrm{fg} \mathrm{C} \mathrm{cell}^{-1}$ and Prochlorococcus $92 \mathrm{fg} \mathrm{C}$ cell $^{-1}$. Approximate picoeukaryotic cell sizes were calculated after examining polycarbonate filters retaining ca $50 \%$ of the respective picophytoplankton group (filters in the range of 8 to $0.45 \mu \mathrm{m}$ pore size were used). Using a

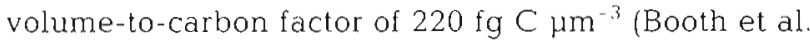
1988), and depending on the variation in scatter signals, a carbon content of 975 (Stn SB2), 1880 (Stn US1) and $2500 \mathrm{fg} \mathrm{C} \mathrm{Cell}^{-1}$ (other stations) was assumed for the small picoeukaryotes, and $5090 \mathrm{fg} \mathrm{C} \mathrm{cell}^{-1}$ for the large picoeukaryotes.

\section{RESULTS}

\section{Hydrography and phytoplankton composition}

Strong northwesterly winds (4 to $7 \mathrm{Bft}$, average 5) prevailed during the investigation period. A sharp thermocline was detected only at the southernmost stations in the Somali Basin, and mixed layer temperatures ranged between 25.4 and $26.9^{\circ} \mathrm{C}$. Mixed layer concentrations of nitrate were low but not depleted in the southern Somali Basin $(0.13$ to $0.23 \mu \mathrm{M})$, but increased substantially in the northern Somali Basin and the Gulf of Aden (0.8 to $1.53 \mu \mathrm{M})$, while in the southern Red Sea, concentrations were as low as 0.02 to $0.4 \mu \mathrm{M}$ (Table 1). Generally, a distinct nutricline coincided with the thermocline. Meteorological conditions and decreasing water temperatures indicated a wind-induced entrainment of nutrient-enriched water from deeper layers into the surface layer, both in the northern Somali Basin (elevated concentrations at US2 and SI) and the Gulf of Aden (GA2). Mixed layer concentrations of phosphate $(0.3$ to $0.5 \mu \mathrm{M})$ and silicate $(1.5$ to $2.5 \mu \mathrm{M})$ were also low but not depleted.

Chlorophyll concentrations were low in the Somali Basin and Gulf of Aden $\left(<0.5 \mu \mathrm{g} \mathrm{dm}^{-3}\right)$; only in the southern Red Sea did chl a concentrations exceed $1 \mu \mathrm{g}$ $\mathrm{dm}^{-3}$ (Table 1). A distinct deep chlorophyll maximum was absent at all stations. Phytoplankton in the Somali Basin was dominated by picoplankton, specifically Synechococcus, Prochlorococcus and some unidentified pico- and nano-eukaryotes. At some stations, subgroups of Synechococcus and Prochlorococcus (dim and bright fluorescent) could be discriminated (Table 2). HPLC (high-performance liquid chromatography) pigment analysis indicated the presence of Prymnesiophyceae, Pelagophyceae, and Micromonastype phytoplankton species (Veldhuis et al. 1994). Dinoflagellates were also abundant during the entire cruise (Gymnodinium and Amphidinium species), while cryptophytes were present only in low numbers. Prochlorococcus was present in the Somali Basin (up to $66000 \mathrm{~cm}^{-3}$ ), but virtually absent in the inner Gulf of Aden and the southern Red Sea, while Synechococcus was present in high abundances (up to $142000 \mathrm{~cm}^{-3}$ ) throughout the cruise. In the Gulf of Aden (GA2) and 
Table 2. Cell concentrations (cells $\mathrm{cm}^{-3}$ ) of photosynthetic picoplankton at the beginning of the experiments analyzed by flow cytometry. Prochlorococcus not analyzed ${ }_{i}-:$ not detected

\begin{tabular}{|c|c|c|c|c|c|c|c|c|c|}
\hline Expt & Stn & Prochlorococcus & Dim & Bright & Synechococcus & Dim & Bright & Small euks & Large euks \\
\hline 1 & SB2 & $-^{\cdot}$ & $-\cdot$ & $-\cdot$ & 67183 & - & - & 6420 & 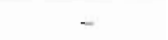 \\
\hline 2 & US1 & $-\cdot$ & $-\cdot$ & $-^{\cdot}$ & 51145 & - & - & 7686 & - \\
\hline 3 & US2 & 50239 & 26777 & 23462 & 43685 & - & - & 5396 & - \\
\hline 4 & SI & 66253 & 40772 & 25481 & 53583 & - & - & 7172 & 812 \\
\hline 6 & GA2 & 13198 & - & - & 142225 & 92784 & 50504 & 18342 & 1601 \\
\hline 8 & RS2 & - & - & - & 47253 & 36845 & 10408 & - & 1162 \\
\hline
\end{tabular}

Table 3. Results of chl a-based dilution grazing experiments (representing the total phytoplankton population). Growth and grazing coefficients derived from dilution plots (apparent growth rate vs dilution factor) according to Landry \& Hassett (1982). Consumption rates calculated according to Frost (1972). ns: linear regressions of dilution plots not signifıcant $(p>0.05)$

\begin{tabular}{|lcccccccc|}
\hline Stn & $\begin{array}{c}\text { Growth } \\
\mu\left(\mathrm{d}^{-1}\right)\end{array}$ & $\begin{array}{c}\text { Grazing } \\
g\left(\mathrm{~d}^{-1}\right)\end{array}$ & $\begin{array}{c}\text { Consumption of } \\
\text { Chl }{ }^{2} \\
\left(\mathrm{mg} \mathrm{m}^{-3} \mathrm{~d}^{-1}\right)\left(\mathrm{mg} \mathrm{m}^{-3} \mathrm{~d}^{-1}\right)\end{array}$ & & & & \\
\hline SB2 & 0.653 & 0.192 & 0.07 & 14.16 & 0.442 & 12 & ns \\
US1 & 0.595 & 0.042 & 0.02 & 3.22 & 0.076 & 12 & ns \\
US2 & 0.520 & 0.201 & 0.08 & 15.33 & 0.630 & 12 & $<0.05$ \\
SI & 0.928 & 0.503 & 0.18 & 34.69 & 0.729 & 12 & $<0.01$ \\
GA1 & 0.399 & 0.148 & 0.12 & 23.71 & 0.534 & 12 & ns \\
GA2 & 0.742 & 0.708 & 0.40 & 75.56 & 0.741 & 12 & $<0.01$ \\
RS1 & 1.123 & 1.187 & 0.78 & 147.81 & 0.942 & $12<<0.01$ \\
RS2 & 0.681 & 0.383 & 0.59 & 111.74 & 0.733 & 12 & $<0.01$ \\
\hline
\end{tabular}

phytoplankton growth rates in the microzooplankton grazing treatments also showed 1 division $\mathrm{d}^{-1}$ on average $(\mu=0.67)_{\text {; }}$ however, piconhytoplankton grazing mortality rates caused by microzooplankton were in the same range, resulting in a quasisteady-state system with grazing losses compensated by growth (filled circles in Fig. 2, Table 5).

Total phytoplankton carbon consumption rates by microzooplankton increased from the Somali Basin (US2 and SI) towards the Gulf of Aden (GA2) and the southern Red Sea (RS1 and RS2; Table 3). There, carbon consumption by microzooplankton was highest $\left(148 \mathrm{mg} \mathrm{m}^{-3} \mathrm{~d}^{-1}\right.$ at RS1). Picophytoplankton carbon con-

the southern Red Sea (RS2), a highly diverse phytoplankton community was found, consisting of large diatoms (Chaetoceros, Nitzschia, Coscinodiscus, Biddulphia), dinoflagellates (Gymnodinium and Amphidinium) and cryptophytes, as well as Phaeocystis-type colonies.

\section{Phytoplankton growth and grazing mortality by microzooplankton}

Results of microzooplankton dilution grazing experiments are summarized in Tables $3 \& 4$. Grazing on total phytoplankton (based on chl a) increased from the southern stations towards the northern Somali Basin, the Gulf of Aden and the southern Red Sea (Table 3). Total phytoplankton (chl a) grazing mortality rates were generally lower than specific growth rates, indicating an overall increase in phytoplankton biomass over time (Fig . 2: chl a, open squares). However, in the Gulf of Aden (GA2) and the southern Red Sea (RS1), specific growth and grazing mortality rates were higher and grazing loss by microzooplankton roughly accounted for total phytoplankton biomass production, i.e. $\mu \approx g$ (Table 3 ). On average, phytoplankton (chl a) divided once a day $(\mu=0.72$; Table 5). Flow cytometrically estimated specific picosumption was relatively conservative throughout the cruise and made up total phytoplankton consumption in the Somali Basin (Fig. 3A; US2 and SI). However, in

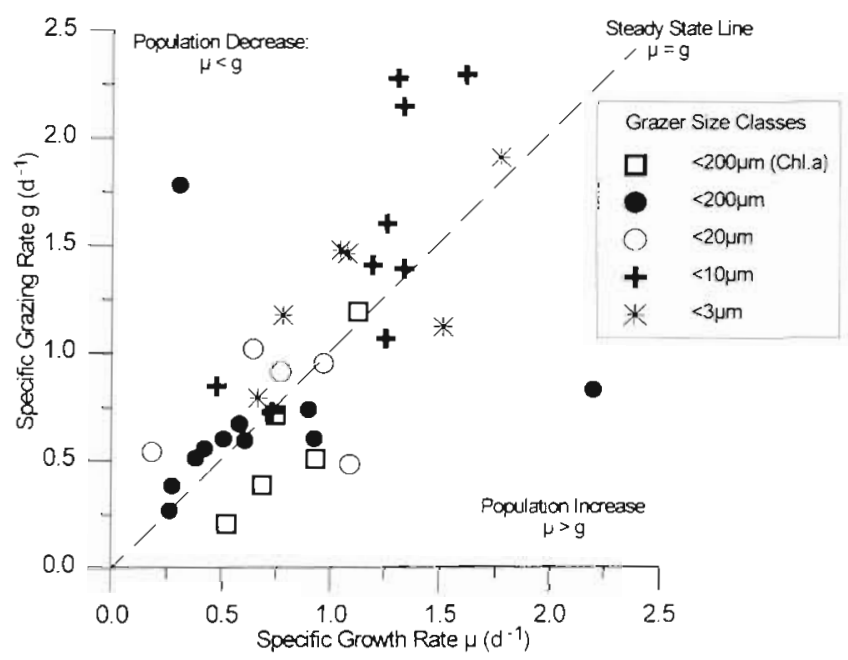

Fig. 2. Relationship between specific growth and grazing mortality rates for phytoplankton, as measured in the serial dilution experiments. Data from Table 4, sorted for the different grazer size class incubations lonly data at $p \leq 0.05$ plotted). Dotted line represents steady-state conditions, where $\mu=g$ 
Table 4. As Table 3, but for picophytoplankton analyzed by flow cytometry in size-fractionation experiments. Results of experiments involvıng grazers $<2 \mu \mathrm{m}$ not shown (ns)

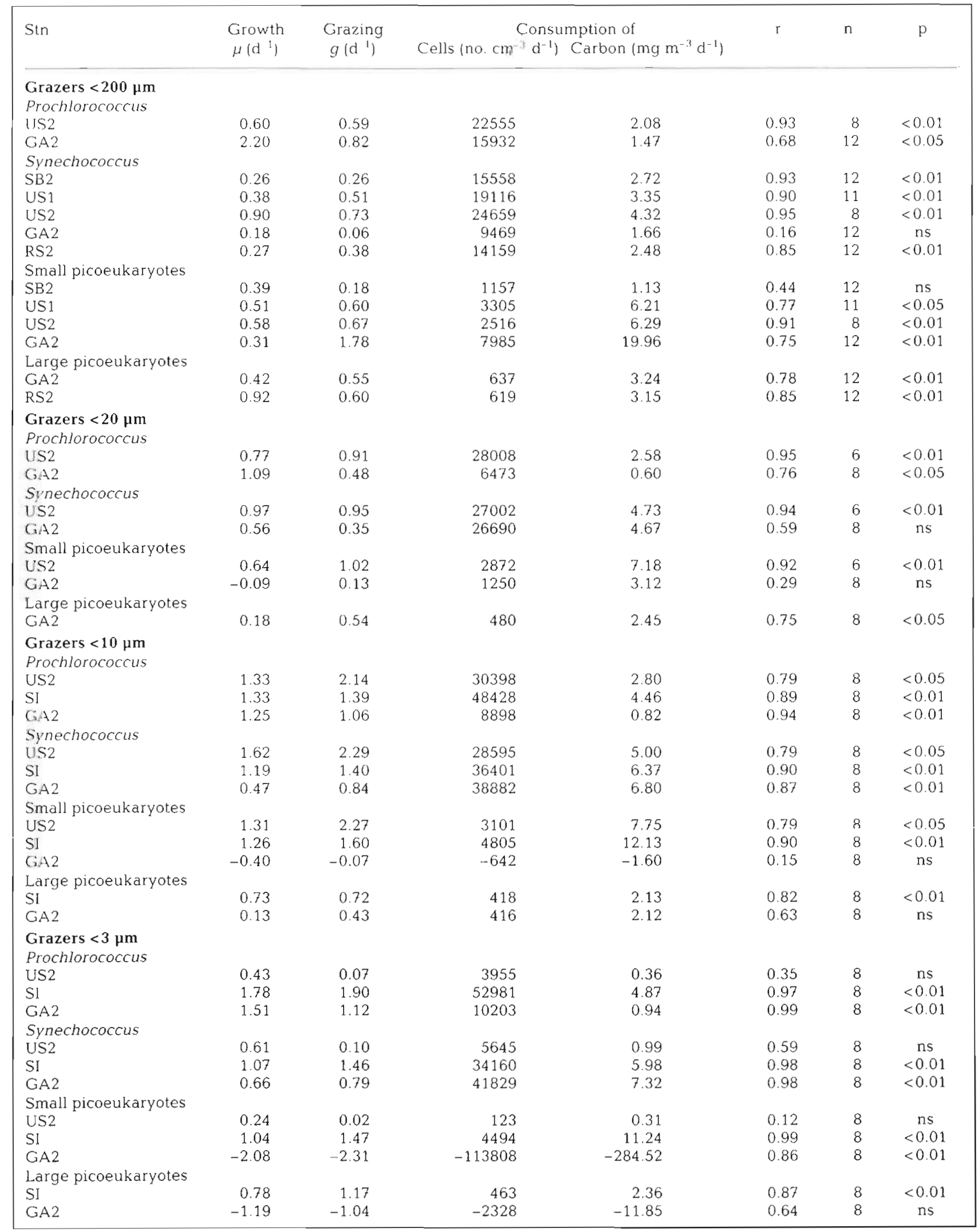


Table 5. Growth and grazing mortality coefficients for total phytoplankton (measured as chl a) and picophytoplankton (analyzed by flow cytometry) in the different grazer size classes, averaged over all stations and picophytoplankton groups. Relative rate increments in the small fractions as compared to the $<200 \mu \mathrm{m}$ size class are given for the picophytoplankton

\begin{tabular}{|llccccrc}
\hline $\begin{array}{l}\text { Grazer } \\
\text { size class }(\mu \mathrm{m})\end{array}$ & Prey type & $\begin{array}{c}\text { Growth } \\
\mu\left(\mathrm{d}^{-1}\right)\end{array}$ & $\begin{array}{c}\text { Relative } \\
\text { increment }(\%)\end{array}$ & $\begin{array}{c}\text { Grazing } \\
g\left(\mathrm{~d}^{-1}\right)\end{array}$ & $\begin{array}{c}\text { Relative } \\
\text { increment }(\%)\end{array}$ & $\begin{array}{c}\text { Consumption }\left(\% \mathrm{~d}^{-1}\right) \text { of } \\
\text { Stock } \\
\text { Prod. }\end{array}$ \\
\hline$<200$ & Total phytoplankton & $0.72 \pm 0.23$ & & $0.48 \pm 0.39$ & & 38 \\
$<200$ & Picophytoplankton & $0.67 \pm 0.56$ & & $0.68 \pm 0.39$ & & 67 \\
$<20$ & Picophytoplankton & $0.73 \pm 0.35$ & +9 & $0.78 \pm 0.25$ & +15 & 54 & 107 \\
$<10$ & Picophytoplankton & $1.17 \pm 0.35$ & +75 & $1.52 \pm 0.60$ & +124 & 78 \\
$<3$ & Picophytoplankton & $1.14 \pm 0.43$ & +70 & $1.32 \pm 0.38$ & +94 & 73 \\
\hline
\end{tabular}

the Gulf of Aden (GA2) and the southern Red Sea (RS2) an increasing amount of phytoplankton carbon was consumed as largor phytoplankton, which was not quantitatively accounted for in the flow cytometric analyses.

Within the picophytoplankton community, the relative importance of picoeukaryotes as food items sharply increased towards the high-chlorophyll Gulf of Aden and Red Sea stations; however, at RS2 they had
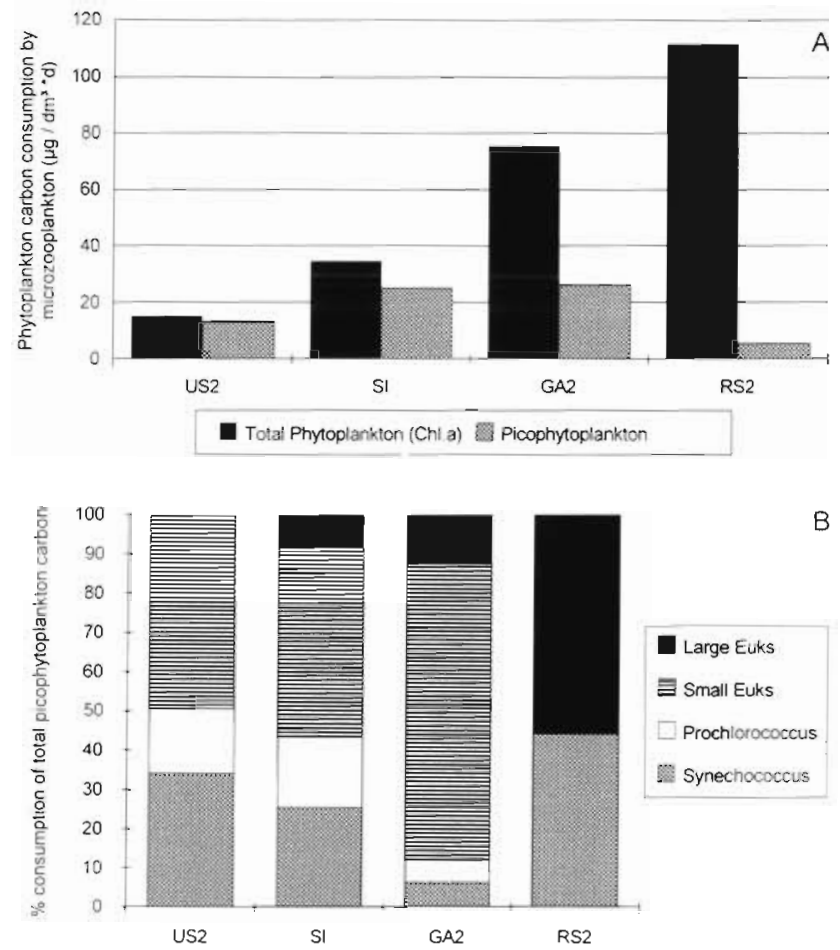

Fig. 3. Phytoplankton carbon consumption rates by microzooplankton i.e. grazers $<200 \mu \mathrm{m}(<10 \mu \mathrm{m}$ at SI $)$ at 4 stations in the Somali Current, the Gulf of Aden and the southern Red Sea. (A) Total phytoplankton (measured as chl a) and picophytoplankton (sum of all groups analyzed by flow cytometry) consumption rates, (B) relative proportions of the respective picophytoplankton groups to total picophytoplankton consumption disappeared completely (Table 2, Fig. 3B). The large picoeukaryotes significantly gained importance in the Gulf of Aden and the Red Sea: while the importance of Prochlorococcus decreased along this transect. Absolute carbon consumption rates were highest for the eukaryotic picoautotrophs (up to $20 \mathrm{mg} \mathrm{m}^{-3} \mathrm{~d}^{-1}$, GA2), whereas Synechococcus (up to $4.3 \mathrm{mg} \mathrm{m}^{-3} \mathrm{~d}^{-1}$, US2) and Prochlorococcus (up to $2.1 \mathrm{mg} \mathrm{m}^{-3} \mathrm{~d}^{-1}$, US2) were generally less important as diet for microzooplankton. As an average over all stations and picophyoplankton groups, microzooplankton $(<200 \mu \mathrm{m})$ was responsible for the removal of $49 \%$ of the picoautotrophic standing stock and $102 \%$ of picoautotrophic production from the water $\mathrm{d}^{-1}$ (Table 5). Relative and absolute picophytoplankton carbon consumption rates (Fig. 4) demonstrate that all groups were grazed according to their stocks, implying no apparent grazing preference for a specific group.

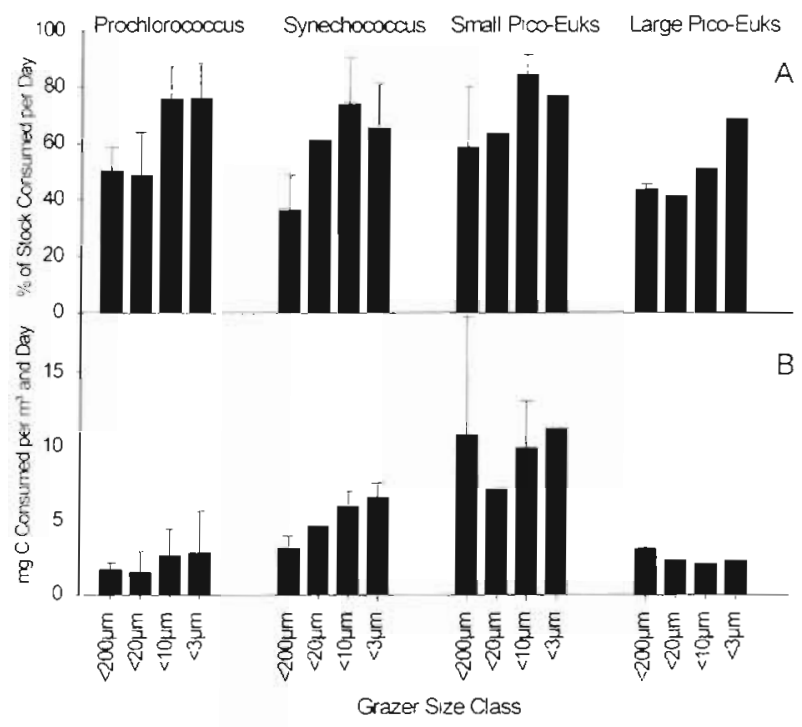

Fig. 4. (A) Relative and (B) absolute consumption rates of 4 picophytoplankton groups in the presence of different grazer size classes. Columns represent means of 2 to 5 experiments (data from Table 4), with standard deviations (only data at $\mathrm{p} \leq 0.05$ plotted) 


\section{Picophytoplankton growth and grazing mortality by nanozooplankton}

Removal of the microzooplankton and larger nanozooplankton (10 to $200 \mu \mathrm{m}$ ) from the incubation water resulted in a considerable increase of grazing pressure on the autotrophic picoplankton (Figs. $2 \& 4$, Table 4). In the samples containing the entire nano$(<20 \mu \mathrm{m})$ and microzooplankton $(<200 \mu \mathrm{m})$, rates for all picoplankton groups were much lower and in the similar range as for chl a (Fig 2). Hence, the larger microzooplankton obviously exerted a strong control over first-order consumers of the picoplankton, thereby relieving the picoplankton from being grazed. As an average over all stations and picophytoplankton groups, grazers $<10$ and $<3 \mu \mathrm{m}$ consumed 78 and $73 \%$ of the picoautotrophic standing stock $\mathrm{d}^{-1}$, and 131 and $115 \%$ of picoautotrophic production $\mathrm{d}^{-1}$, respectively (Table 5). The prokaryotic genera Prochlorococcus and Synechococcus, as well as the small eukaryotic picoautotrophs, experienced the highest growth and grazing mortality rates in the small size fractions $<10$ and $<3 \mu \mathrm{m}$; the rates for the large picoeukaryotes in these fractions were lower (Table 4).

At some stations, sub-populations of Prochlorococcus and Synechococcus could be analyzed, termed 'dim' and 'bright', according to their red fluorescence intensity (Table 2). While the 2 sub-groups of Synechococcus showed similar growth and grazing rates, the dynamics of the 2 sub-populations of Prochlorococcus were remarkably different: the 'dim' type showed growth rates slightly exceeding grazing mortality, whereas the 'bright' type virtually did not grow but experienced the same grazing pressure as the 'dim' type (Fig. 5), consequently it decreased in biomass. As for all analyzed picoautotrophic groups, growth and grazing mortality rates were dramatically elevated in the absence of grazers $>10 \mu \mathrm{m}$.

\section{DISCUSSION}

\section{Phytoplankton growth and grazing mortality by microzooplankton}

Our data indicate a highly dynamic turnover of autotrophic picoplankton in the western Arabian Sea. Picophytoplankton divided roughly once a day, the same rate at which they were removed from the water column by microzooplankton grazing. This implies a balanced steady-state system with respect to this very small phytoplankton. However, we found that larger phytoplankton biomass could increase with specific growth rates exceeding grazing mortality rates. The same effect was described in the equa-

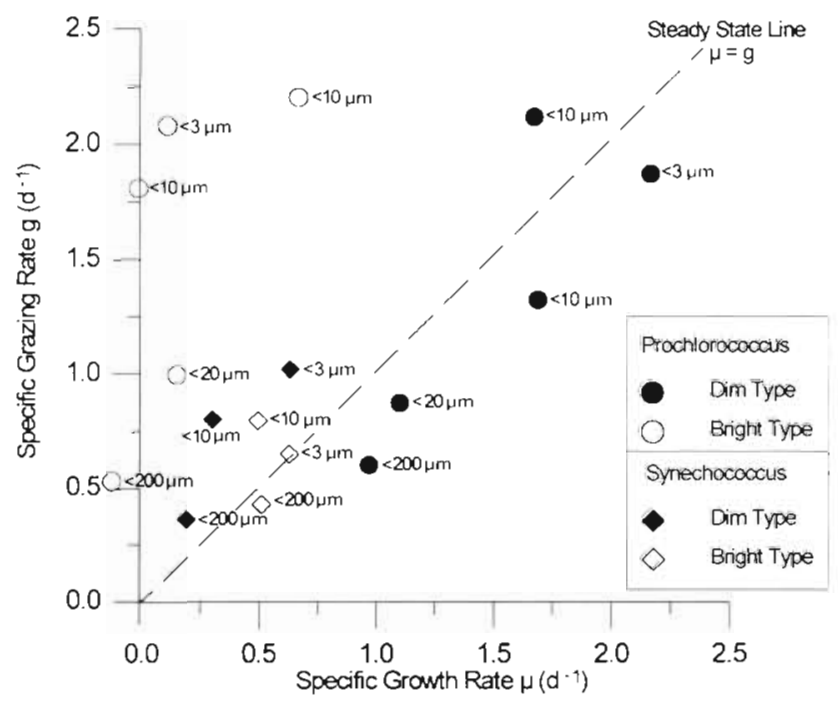

Fig. 5. As Fig. 2, for 2 Prochlorococcus and Synechococcus sub-populations ('dim' and 'bright' types). Respective grazer size classes are indicated for each data point (only data at $\mathrm{p} \leq 0.05$ plotted)

torial Pacific by Landry et al. (1995a, b), where they found chlorophyll-based growth rates exceeding grazing estimates, while the picoautotrophic community was more or less in balance or experienced a net decrease due to high grazing rates at concomitantly lower growth rates. As mesozooplankton, the potent grazers of the large phytoplankton, had been removed from the incubations $(<200 \mu \mathrm{m})$, the large phytoplankton could increase in biomass. On the other hand, the microbial food web remained more or less unaffected in these treatments, resulting in a balanced system. The proportion of larger phytoplankton increased along the transect from the Somali Current into the Gulf of Aden and the Red Sea, and was increasingly utilized by microzooplankton, whereas the proportion provided by picoautotrophs remained relatively constant (Fig. 3A). As the C:chl a ratio we used (190) was determined by flow cytometry (Veldhuis et al. 1997), it may overestimate phytoplankton carbon values at stations rich in chlorophyll (Gulf of Aden and Red Sea) to a certain extent; for stations low in chlorophyll, however, such high ratios are reasonable (as discussed in detail by Buck et al. 1996). However, our interpretation with respect to the relative importance of the picoautotrophic organisms as a diet for the microzooplankton remains unaffected.

Within the picoautotrophic compartment, eukaryotes gained importance with increasing chlorophyll concentrations, while Prochlorococcus decreased in concentration along this gradient and was virtually absent in the southern Red Sea. This confirms recent 
observations demonstrating Prochlorococcus to be a true open-ocean organism, largely restricted to oligotrophic warm stratified waters (Lindell \& Post 1995, Suzuki et al. 1995, Buck et al. 1996). However, hardly any rate estimates have been published for Prochlorococcus. Goericke \& Welschmeyer (1993) found relatively low growth rates in the Sargasso Sea (below 1 division $\mathrm{d}^{-1}$ ), while Vaulot et al. (1995) report on division rates of $1 \mathrm{~d}^{-1}$ in the surface layer of the equatorial Pacific. Growth and grazing estimates from the same region are presented by Landry et al. $(1995 \mathrm{a}, \mathrm{b})$ : in their experiments, Prochlorococcus grazing mortality considerably exceeded specific growth rates, which were extraordinarily low (mostly $\mu=0$ to $0.26 \mathrm{~d}^{-1}$ ). The existence of 2 different strains of Prochlorococcus had been demonstratcd carlicr in the subtropical North Atlantic on the basis of pigment types (Goericke \& Repeta 1993) and different chlorophyll and DNA contents at the HOT site (Hawaii, subtropical North Pacific; Campbell \& Vaulot 1993). The data presented here suggest that the 2 sub-populations also may experience different growth characteristics, with an apparently healthy growing population ('dim') and a hardly active one ('bright'; Fig. 5).

Phytoplankton grazing estimates from the Arabian Sea have been reported so far only by Burkill et al. (1993). During the autumn inter-monsoon period, they found Synechococcus to be a highly abundant and dynamic component of the food web, with growth and grazing mortality well in balance. Synechococcus was the dominant picoautotroph during our investigations in terms of cell numbers, but the picoeukaryotes, due to their larger size, dominated in terms of carbon biomass. They were the most important picoautotrophic carbon source for the microzooplankton (Fig. 3B). Prochlorococcus was less abundant by a factor of 4 during the NE monsoon (up to $66000 \mathrm{~cm}^{-3}$ ) than during the spring inter-monsoon (up to $276000 \mathrm{~cm}^{-3}$; Veldhuis \& Kraay 1993), so its contribution to micro- and nanozooplankton diet was rather low during this season. However, at abun- dances typical for oligotrophic conditions (up to $350000 \mathrm{~cm}^{-3}$; e.g. Campbell \& Vaulot 1993, Morel et al. 1993, Lindell \& Post 1995, Buck et al. 1996), the nutritional importance of Prochlorocuccus might be equal to, or even higher than, that of Synechococcus or the picoeukaryotes.

The size-fractionation experiments suggest that small heterotrophic nanoflagellates (HNF) are the main consumers of Prochlorococcus, Synechococcus and picoeukaryotes in the Arabian Sea. Epifluorescence analysis revealed that the vast majority of HNF (>90\%) was smaller than $3 \mu \mathrm{m}$, with the biomass peak still within the $<5 \mu \mathrm{m}$ size range (data not shown). Small HNF are known to be mainly responsible for the removal of heterotrophic bacteria (e.g. Fenchel 1986): but are also able to consume coccoid cyanobacteria in situ (Caron et al. 1991). Parslow et al. (1986) reported that the small HNF Pseudobodo $(2 \times 4 \mu \mathrm{m})$ is capable of rapidly reproducing on the picoeukaryotic alga Micromonas pusilla (1 to $2 \mu \mathrm{m}$ ) as sole food source. Calculations assuming HNF to be the only consumers of picoautotroph carbon imply that they could well be able to satisfy their daily carbon demand exclusively from this source (up to $1200 \%$ of their own body carbon consumed $\mathrm{d}^{-1}$; Table 6 : daily ration). Although this assumption is a simplification (larger protozod will probably contribute to the removal of picoautotroph carbon to a certain extent, and heterotrophic bacteria will still be a major diet for HNF), it nevertheless shows that $<3 \mu \mathrm{m}$ HNF may apply a vigorous grazing pressure on picophytoplankton. There is also direct microscopical evidence for the ingestion of autotrophic picoplankton by HNF: a large number of $\mathrm{HNF}<3 \mu \mathrm{m}$ contained 1 or 2 whole or partly digested Synechococcus cells, which can be identified reliably by their bright yellow autofluorescence under blue excitation. Although some dinoflagellates also contained Synechococcus cells, their frequency was much lower than the Synechococcuscontaining HNF. Ciliates containing Synechococcus cells were not detected.

Table 6. Absolute picophytoplankton carbon consumption rates as the sum of all picophytoplankton groups in the $<200 \mu m$ fractions (SI: $<10 \mu \mathrm{m}$ ) at 4 stations in the Somali Current, the Gulf of Aden, and the Red Sea. Ambient HNF and total protozoan biomasses (HNF + ciliates + heterotrophic dinoflagellates) are given to estimate dally rations of the grazers (prey carbon ingested as \% of grazer body carbon). Protozoan biomasses were derived from epifluorescence counts (data not shown) according to the JGOFS protocols (Knap et al. 1994\}

\begin{tabular}{|c|c|c|c|c|c|}
\hline \multirow[t]{2}{*}{$\operatorname{Sin}$} & \multirow{2}{*}{$\begin{array}{l}\text { Picophytoplankton } \\
\text { consumption } \\
\left.\text { (mg m } \mathrm{m}^{-3} \mathrm{~d}^{-1}\right)\end{array}$} & \multicolumn{2}{|c|}{ HNF } & \multicolumn{2}{|c|}{ Total protozoa } \\
\hline & & $\begin{array}{l}\text { C biomass } \\
\left(\mathrm{mg} \mathrm{m}^{-3}\right)\end{array}$ & $\begin{array}{l}\text { Daily ration } \\
\text { of HNF }(\%)\end{array}$ & $\begin{array}{l}\text { C biomass } \\
\left(\mathrm{mg} \mathrm{m}^{-3}\right)\end{array}$ & $\begin{array}{c}\text { Daily ration } \\
\text { of protozoa }(\%)\end{array}$ \\
\hline US2 & 12.68 & 2.98 & 426 & 4.84 & 262 \\
\hline SI & 25.08 & 2.12 & 1183 & 4.59 & 546 \\
\hline GA2 & 26.33 & 2.92 & 902 & 4.61 & 571 \\
\hline RS2 & 5.63 & 1.90 & 296 & 7.18 & 78 \\
\hline
\end{tabular}




\section{Multiple trophic interactions within the microbial food web}

The number of trophic levels within the microzooplankton community and the size of the principal grazers of picoplankton are important variables when estimating carbon flux in picoplankton-dominated systems. Eukaryotic and prokaryotic bacterivores have been found in the bacterial size class, i.e. 0.2 to $2 \mu \mathrm{m}$ (Fuhrman \& McManus 1984, Guerrero et al. 1986). Wikner \& Hagström (1988) presented experimental evidence for the existence of 4 trophic levels in the size class $<12 \mu \mathrm{m}$, with the primary bacterivores being smaller than $3 \mu \mathrm{m}$ and controlled by the larger protozoa. Glibert et al. (1992) found a similar effect in sizefractionated grazing and $\mathrm{NH}_{4}{ }^{+}$regeneration experiments in Chesapeake Bay (USA) waters. When organisms $>10 \mu \mathrm{m}$ were removed from their incubations, ammonium regeneration rates increased significantly.

A linkage between the predators of the first-order consumers and the prey is a well-known feature in terrestrial ecology and limnology (trophic cascade; Carpenter et al. 1985, Strong 1992) and has recently also been described for marine pelagic food webs of different trophic conditions (Wikner \& Hagström 1988. Weisse \& Scheffel-Möser 1991, Hansen et al. 1993, reviewed in Verity \& Smetacek 1996). For the Red Sea, Weisse (1989) reported on a 2-step protozoan food chain. heterotrophic bacteria profit from larger protozoa feeding on the major bacterivores, the HNF. Our data indicate that this effect also applies to the autotrophic picoplankton in the region. The enhanced grazing pressure on picophytoplankton in the absence of grazers $>10$ and $>3 \mu \mathrm{m}$ demonstrates that first-order consumers of picoplankton (i.e. the small HNF) are preyed upon by larger nanozooplankton and microzooplankton in the field, which act as carbon mediators from picoplanktonic autotrophs to higher trophic levels. The extent of this transfer largely depends on the metabolic rates of the primary consumers of the autotrophic picoplankton.

The elevated grazing rates in the fractions $<10 \mu \mathrm{m}$ may be due either to an increased per cell ingestion rate at constant grazer biomass, or to an increased grazer biomass at constant per cell ingestion rates. The former possibility seems unlikely as initial prey concentrations were identical in all parallel size fractionations; hence, an adjustment of the individual feeding effort as a reaction to different prey concentrations can be excluded. Moreover, extraordinarily high HNF growth rates have been measured in the absence of large predators by various authors $\left(\mu>2 \mathrm{~d}^{-1}\right.$, corresponding to more than 3 doublings $\mathrm{d}^{-1}$; Sherr et al. 1983, Parslow et al. 1986, Kuosa 1991). Thus, if we assume that the increased grazing rates are symptomatic of an increased grazer biomass, it is possible to roughly estimate grazer growth and predation mortality rates from the size-fractionated experiments. It can then be estimated that grazers $<10 \mu \mathrm{m}$ more than doubled their biomass within $1 \mathrm{~d}$ when predators $>10 \mu \mathrm{m}$ were removed (increase of $124 \%$; Table 5), which is a realistic figure (see above). When these results are extrapolated to field conditions, this means that small HNF, like their prey, divide once a day, and are removed by their predators at a similar rate. This is a strong indication for the presence of a trophic cascade encompassing at least 3 trophic levels within the nanoplankton: picoautotrophs - small HNF - larger protozoa.

In our experiments, the picophytoplankton also increased their specific growth rates when they were exposed to an increased grazing pressure (on average by $75 \%$ in the $<10 \mu \mathrm{m}$ fractions relative to the $<200 \mu \mathrm{m}$ fractions; Table 5, Fig 2). A close coupling between prey growth rates and grazing pressure (mediated by enhanced nutrient regeneration) has long been acknowledged as a prerequisite for the functioning of the microbial loop and has been demonstrated in laboratory and field experiments (i.e. Goldman \& Caron 1985, Rassoulzadegan \& Sheldon 1986, Berman et al. 1987, Wikner \& Hagström 1988). Similar to our findings, Glibert et al. (1992) found ammonium regeneration rates to be substantially higher in their $<10 \mu \mathrm{m}$ fractions as compared to the $<200 \mu \mathrm{m}$ fractions, and Ferrier \& Rassoulzadegan (1991) demonstrated that autotrophic pico- and nanoplanktonic growth was limited by protozoan standing stocks or their remineralizing, i.e. grazing, activity. Our data indicate that this linkage between grazer and prey may hold true also in the presence of considerable amounts of new nutrients, at least for the prokaryotic picoautotrophs and the small picoeukaryotes. Such a preferential uptake of ammonium in small phytoplankton cells in the presence of excess nitrate has been demonstrated in the field (Harrison \& Wood 1988, Wheeler \& Kokkinakis 1990, Price et al. 1994). These observations strongly substantiate the notion of the ubiquitous nature of this tight coupling between the smallest phytoplankton and their primary grazers, with grazing mortality and growth as the 2 sides of the coin.

Our data imply the existence of a multi-step food chain with respect to the small phytoplankton in the Arabian Sea, as had been demonstrated earlier for heterotrophic bacteria in the same region (Weisse 1989). On the one hand, this means that a certain amount of phytogenic carbon is forwarded from the autotrophic picoplankton via small heterotrophic flagellates and larger protozoa to the mesozooplankton; on the other hand, the high turnover rates and the size 
of these first-order consumers indicate that this amount of picoplanktonic primary production reaching higher trophic levels will be smaller than in systems with larger herbivores. In such a system, where tiny primary producers (closely coupled to their grazers) represent the major fraction of primary production, recycling of nutrients and respiration within the euphotic zone will be quite high. As we believe that the mechanisms described also apply to other oceans, the resulting great potential to recycle $\mathrm{CO}_{2}$ in the euphotic zone may help explain the minimal effect of iron fertilization on sea-surface $\mathrm{CO}_{2}$ concentrations (Watson et al. 1994) within the framework of the IRONEX I experiment (Martin et al. 1994), as supposed by Banse (1995). Although IRONEX II (Coale et al. 1996) succeeded in triggering a diatom uloun (biomâss increase $85 \times$ ), associated with a considerable decrease of $\mathrm{CO}_{2}$ in surface waters (Cooper et al. 1996), picophytoplankton only doubled in biomass, and was tightly coupled to microzooplankton (i.e. protozoan) biomass. This observation gives further evidence for a tightly coupled picophytoplankton-protozoa link which itself is rather loosely coupled to the food web involving larger organisms.

Acknowledgements. We thank Drs Martien A. Baars, Peter H. Burkill, Bodo von Bodungen, Falk Pollehne and Karin Lochte for lively discussions and critical reading of earlier versions of the manuscript, Gjisbert W. Kraay for supplying the chlorophyll data, and Karel M. J. Bakker for the nutrient data. Special thanks to the chief scientist of the project B-cruises of the Netherlands Indian Ocean Programme, Martien Baars, and to the dedicated technical staff and crew of RV 'Tyro'

\section{LITERATURE CITED}

Baars MA, Bakker KMJ, de Bruin TF, van Couwelaar $M$, Hiehle MA, Kraay GW, Oosterhuis SS, Schalk PH, Sprong I, Veldhuis MJW, Wiebinga CJ, Witte JIJ (1994) Seasonal fluctuations in plankton biomass and productivity in the ecosystems of the Somali Current, the Gulf of Aden and southern Red Sea. In: Baars MA (ed) Monsoons and pelagic systems. Cruise Report Vol 1 of the Netherlands Indian Ocean Programme, National Museum of Natural History, Leiden, p 13-34

Banse K (1995) Community response to IRONEX. Nature 375 : 112

Berman T, Nawrocki M, Taylor CT, Karl DM (1987) Nutrient flux between bacteria, bacterivorous nanoplankton protists and algae. Mar Microb Food Webs 2(2):69-82

Booth BC, Lewin J, Lorenzen CJ (1988) Spring and summer growth rates of subarctic Pacific phytoplankton assemblages determined from carbon uptake and cell volumes estimated using epifluorescence microscopy. Mar Biol 98: $287-298$

Buck KR. Chavez FP, Campbell L (1996) Basin-wide distributions of living carbon components and the inverted trophic pyramid of the central gyre of the North Atlantic Ocean, summer 1993. Aquat Microb Ecol 10:283-289

Burkill PH, Leakey RJG, Owens NJP, Mantoura RFC (1993) Synechococcus and its importance to the microbial food web of the northwest Indian Ocean. Deep Sea Res II 40: $773-782$

Campbell L. Nolla HA, Vaulot D (1994) The importance of Prochlororncrus to community structure in the central North Pacific Ocean. Limnol Oceanogr 39(4):954-961

Campbell L. Vaulot D (1993) Photosynthetic picoplankton community structure in the subtropical North Pacific Ocean near Hawaii (station ALOHA). Deep Sea Res I 40(10):2043-2060

Caron DA, Lim EL, Miceli G, Waterbury JB, Valois FW (1991) Grazing and utilization of chroococcoid cyanobacteria and heterotrophic bacteria by protozoa in laboratory cultures and a coastal community. Mar Ecol Prog Ser 76: 205-217

Carpenter SR, Kitchell JF, Hodgson JR (1985) Cascading trophic interactions and lake productivity. BioSci $35(10)$ : $634-639$

Chisholm SW, Frankel SL, Goericke R, Olson RL, Palenik B, Waterbury JB, West-Johnsrud L, Zettler ER (1992) Prochlorococcus marinus nov. gen. nov. spec.: an oxyphototrophic marine prokaryote containing divinyl chlorophyll $a$ and $b$. Arch Microb 157:297-300

Coale $\mathrm{KH}$ and 1.9 co-workers (1996) A massive phytoplankton bloom induced by an ecosystem-scale iron fertilization experiment in the equatorial Pacific Ocean. Nature 383: 495-501

Cooper DJ, Watson AJ, Nightingale PD (1996) Large decrease in ocean-surface $\mathrm{CO}_{2}$ fugacity in response to in situ fertilization. Nature 383:511-513

Fenchel T (1986) The ecology of heterotrophic microflagellates. Adv Microb Ecol 9:57-97

Ferrier C, Rassoulzadegan F (1991) Density-dependent effects of protozoans on specific growth rates in pico- and nanoplanktic assemblages. Limnol Oceanogr 36(4):657-669

Fogg GE (1995) Some comments on picoplankton and its importance in the pelagic ecosystem. Aquat Microb Ecol 8:33-39

Frost BW (1972) Effects of size and concentration of food particles on the feeding behaviour of the manne planktonic copepod Calanus pacificus. Limnol Oceanogr 17(6) 805-815

Fuhrman JA, McManus GB (1984) Do bacteria-sized marine eukaryotes consume significant bacterial production? Science 224:1257-1260

Glibert PM, Miller CA, Garside C, Roman MR, McManus GB (1992) $\mathrm{NH}_{4}{ }^{+}$regeneration and grazing: interdependent processes in size fractionated ${ }^{15} \mathrm{NH}_{4}{ }^{+}$experiments. Mar Ecol Prog Ser 82:65-74

Goericke R, Repeta DJ (1993) Chlorophylls $a$ and $b$ and divinyl chlorophylls $a$ and $b$ in the open subtropical North Atlantic Ocean. Mar Ecol Prog Ser 101:307-313

Goericke R, Welschmeyer NA (1993) The marine prochlorophyte Prochlorococcus contributes significantly to phytoplankton biomass and primary production in the Sargasso Sea. Deep Sea Res I 40(11/12):2283-2294

Goldman JC, Caron DR (1985) Experimental studies on an omnivorous microflagellate: implications for grazing and nutrient regeneration in the marine microbial food chain. Deep Sea Res 32(8):899-915

Guerrero R, Pedros-Alio C, Esteve I, Mas J, Chase D, Margulis L (1986) Predatory prokaryotes: predation and primary consumption evolved in bacteria. Proc Natl Acad Sci USA 83:2138-2142

Hansen FC, Reckermann M, Klein Breteler WCM, Riegman R (1993) Phaeocystis blooming enhanced by copepod predation on protozoa: evidence from incubation experiments. Mar Ecol Prog Ser 102:51-57 
Harrison WG, Wood LJE (1988) Inorganic nitrogen uptake by marine picoplankton: evidence for size partitioning Limnol Oceanogr 33(3):468-475

Jochem FJ (1995) Phototrophic picoplankton community structure in three different pelagic regimes in the Arabian Sed. Mar Ecol Prog Ser 117:307-314

Johnson PW, Sieburth JM (1979) Chroococcoid cyanobacteria in the Sea: a ubiquitous and diverse phototrophic biomass Limnol Oceanogr 24:928-935

Johnson PW, Sieburth JM (1982) In-situ morphology and occurrence of eukaryotic phototrophs of bacterian size in the picoplankton of estuarine and oceanic waters. J Phycol 18:318-327

Knap A, Michaels A, Close A, Ducklow H, Dickson A (eds) (1994) Protocols for the Joint Global Ocean Flux Study (JGOFS) Core Measurements. JGOFS Report No. 19. Reprint of the IOC Manuals and Guides No. 29, UNESCO 1994 Internet address: http://ads.smr.uib.no/jgofs/publicat.htm

Kuosa H (1991) Picoplanktic algae in the northern Baltic Sea: seasonal dynamics and flagellate grazing. Mar Ecol Prog Ser 73:269-276

Landry MR, Hassett RP (1982) Estimating the grazing impact of marine micro-zooplankton. Mar Biol 67:283-288

Landry MR, Kirshtein J, Constantinou J (1995a) A refined dilution technique for measuring the community grazing impact of microzooplankton, with experimental tests in the central equatorial Pacific. Mar Ecol Prog Ser 120:53-63

Landry MR, Kirshtein J, Constantinou J (1995b) Microzooplankton grazing in the central equatorial Pacific during February and August 1992. Deep Sea Res ll 42(2-3): $657-671$

Lindell D, Post AF (1995) Ultraphytoplankton succession is triggered by deep winter mixing in the Gulf of Aqaba (Eilat), Red Sea. Limnol Oceanogr 40(6):1130-1141

Lochte K, Turley CM (1988) Bacteria and cyanobacteria associated with phytodetritus in the deep sea. Nature 333 $67-69$

Martin JH and 44 co-workers (1994) Testing the iron hypothesis in ecosystems of the equatorial Pacific Ocean. Nature 371:123-129

Monger BC, Landry MR (1993) Flow cytometric analysis of marine bacteria with Hoechst 33342. Appl Environ Microbıl 59:905-911

Morel A, Ahn YH, Partensky F, Vaulot D, Claustre H (1993) Prochlorococcus and Synechococcus: a comparative study of their optical properties in relation to their size and piqmentation. J Mar Res 51:617-649

Olson RJ, Chisholm SW, Zettler ER, Altabet MA, Dusenberry JA (1990) Spacial and temporal distributions of prochlorophyte picoplankton in the North Atlantic Ocean. Limnol Oceanogr 37(6): 1033-1051

Parslow JS, Doucette GJ, Taylor FJR, Harrison PJ (1986) Feeding by the zooflagellate Pseudobodo sp. on the picoplanktonic prasinomonad Micromonas pusilla. Mar Ecol Prog Ser 29:237-246

Pollehne F, Klein B, Zeitzschel B (1993) Low light adaptation and export production in the deep chlorophyll maximum layer in the northern Indian Ocean. Deep Sea Res II 40 $737-752$

Price NM, Ahner BA, Morel FMM (1994) The equatorial Pacific Ocean: grazer-controlled phytoplankton populations in an iron-limited ecosystem. Limnol Oceanogr 39(3):520-534

Rassoulzadegan F, Sheldon RW (1986) Predator-prey interactions of nanozooplankton and bacteria in an oligotrophic marine environment. Limnol Oceanogr 31(5):1010-1021
Sherr BF, Sherr EB, Berman T (1983) Grazing, growth and ammonium excretion rates of a heterotrophic microflagellate fed with four species of bactena. Appl Environ Microbrol 45(4):1196-1201

Sherr EB, Sherr BF, Paffenhöfer GA (1986) Phagotrophıc protozoa as food for metazoans: a 'missing' trophic link in marne pelagic food webs? Mar Microb Food Webs 1(2):61-80

Sieracki ME, Haugen EM, Cucci TL (1995) Overestimation of heterotrophic bacteria in the Sargasso Sea: direct evidence by flow and imaging cytometry. Deep Sea Res I 42(8): 1399-1409

Simon N, Barlow RG, Marıe D, Partensky F, Vaulot D (1994) Characterization of oceanic photosynthetic picoeukaryotes by flow cytometry. J Phycol 30:922-935

Strong DR (1992) Are trophic cascades all wet? Differentiation and donor-control in speciose ecosystems. Ecology 73(3): $747-754$

Suzuki K, Handa N, Kiyosawa H, Ishizaka J (1995) Distribution of the prochlorophyte Prochlorococcus in the central Pacific Ocean as measured by HPLC. Limnol Oceanogr 40(5):983-989

Vaulot D, Marie D, Olson RJ, Chisholm SW (1995) Growth of Prochlorococcus, a photosynthetic prokaryote, in the equatorial Pacific Ocean. Science 268:1480-1482

Veldhuis MJW, Kraay GW (1993) Cell abundance and fluorescence of picoplankton in relation to growth irradiance and nitrogen availability in the Red Sea. Neth $J$ Sea Res 31:135-145

Veldhuis MJW, Kraay GW, Gieskes WWC (1993) Growth and fluorescence characteristics of ultraplankton on a northsouth transect in the eastern North Atlantic. Deep Sea Res 40:609-626

Veldhuis MJW, Kraay GW, van Bleijswijk J (1994) Phytoplankton biomass and productivity. In: Baars MA (ed) Monsoons and pelagic systems. Cruise Report Vol 1 of the Netherlands Indian Ocean Programme, National Museum of Natural History, Leiden, p 45-54

Veldhuıs MJW, Kraay GW, van Bleijswijk J, Baars MA (1997) Seasonal and spatial variability of phytoplankton biomass, productivity and growth in the north-western Indian Ocean (the SW and NE monsoon 1992-1993). Deep Sea Res I (in press)

Verity PG, Smetacek V (1996) Organism life cycles, predation, and the structure of marine pelagic ecosystems. Mar Ecol Prog Ser 130:277-293

Waterbury JB, Watson SB. Guillard RRL, Brand LE (1.979) Widespread occurrence of a unicellular, marine, planktonic cyanobacterium. Nature 277:293-294

Watson AJ and 10 co-workers (1994) Minimal effects of iron fertilization on sea-surface carbon dioxide concentrations. Nature 371:143-145

Weisse T (1989) The microbial loop in the Red Sea: dynamics of pelagic bacteria and heterotrophic nanoflagellates. Mar Ecol Prog Ser 55:241-250

Weisse T, Scheffel-Moser U (1991) Uncoupling the microbial loop: growth and grazing loss rates of bacteria and heterotrophic nanoflagellates in the North Atlantic. Mar Ecol Prog Ser 71:195-205

Wheeler PA, Kokkinakis SA (1990) Ammonium recycling limits nitrate use in the oceanic subarctic Pacific. Limnol Oceanogr 35:1267-1278

Wikner J, Hagström $\AA$ (1988) Evidence for a tightly coupled nanoplanktonic predator-prey link regulating the bacterivores in the marine environment. Mar Ecol Prog Ser 50: $137-145$

Manuscript first received: April 4, 1995

Revised version accepted: February 3, 1997 